\title{
Risk factors for human brucellosis among a pastoralist community in South-West Kenya, 2015
}

\author{
Mathew Muturi ${ }^{1 *} \mathbb{D}$, Austine Bitek ${ }^{2}$, Athman Mwatondo ${ }^{1}$, Eric Osoro ${ }^{3}$, Doris Marwanga ${ }^{4}$, Zeinab Gura ${ }^{5}$, \\ Phillip Ngere ${ }^{6}$, Zipporah Nganga ${ }^{7}$, S. M. Thumbi ${ }^{3,5}$ and Kariuki Njenga ${ }^{3}$
}

\begin{abstract}
Objective: Brucellosis is one of the top five priority zoonosis in Kenya because of the socio-economic burden of the disease, especially among traditional, livestock keeping communities. We conducted a 1 year, hospital based, unmatched case-control study to determine risk factors for brucellosis among Maasai pastoralists of Kajiado County in 2016. A case was defined by a clinical criteria; fever or history of fever and two clinical signs suggestive of brucellosis and a positive competitive enzyme-linked immunosorbent assay test (c-ELISA). A control was defined as patients visiting the study facility with negative c-ELISA. Unconditional logistic regression was used to study association between exposure variables and brucellosis using odds ratios (OR) and 95\% confidence intervals (Cl).

Results: Forty-three cases and 86 controls were recruited from a population of 4792 individuals in 801 households. The mean age for the cases was 48.7 years while that of the controls was 37.6 years. The dominant gender for both cases (62.7\%) and controls (58.1\%) groups was female. Regular consumption of un-boiled raw milk and assisting animals in delivery were significantly associated with brucellosis by OR $7.7(95 \% \mathrm{Cl} 1.5-40.1)$ and OR $3.7(95 \% \mathrm{Cl} 1.1-13.5)$, respectively.
\end{abstract}

Keywords: Brucellosis, Risk factors, Kenya

\section{Introduction}

Brucellosis is a debilitating febrile illness in humans and reproductive disease of livestock, caused by bacteria of the genus Brucella [1]. There are six Brucella species based on primary host preference, but only four have zoonotic potential; B. melitensis (goats and sheep), Brucella abortus (cattle), B. suis (swine) and B. canis (dogs) [2-5]. Human infection occurs through direct contact with infected animal tissues like products of abortion and blood or ingestion of unpasteurized milk and dairy products $[2,6]$. Although livestock are the primary source of human infection, wild animals may act as reservoirs in regions with human-wildlife interaction [7, 8]. Human brucellosis presents as an acute to chronic

\footnotetext{
*Correspondence: muturimathew@gmail.com

${ }^{1}$ Kenya Zoonotic Disease Unit-Ministry of Agriculture, Livestock and Fisheries and Ministry of Health, P.O. Box 20811-00202, Nairobi, Kenya Full list of author information is available at the end of the article
}

illness characterized by fever and other constitutional symptoms such as joint pains, fatigue and muscle ache that vary with the stage of infection and body system affected $[9,10]$. The disease has a low mortality rate, but the relapsing and chronic nature of human infection, the long cause of treatment and negative implication on livestock trade qualifies brucellosis as a serious public health and socio-economic problem [2, 9, 11-15].

Brucellosis is the most common zoonotic infection globally with more than half a million human cases annually, however, infection rates vary significantly between developed and developing countries $[1,16,17]$. The human disease has been eliminated in most developed countries like Canada, Japan and Australia but remains endemic in most developing countries in Asia, the Middle East, Eastern Europe, Latin America and Africa [1, 16, 18-20].

In Kenya, brucellosis is ranked as a top priority zoonosis due to the socio-economic burden and amenability 
to control, however, as is common with other neglected zoonotic diseases, establishing the true morbidity and socio-economic impact of the disease is a challenge because of misdiagnosis and underreporting [21]. Studies in Kenya indicate high prevalence in humans and livestock although this varies with geographical region and livestock production system [22-27]. Brucellosis is endemic in Kenya and identifying potential risk factors of brucellosis among the most vulnerable populations; primarily rural livestock keeping communities is important in defining control and prevention strategies. We conducted a case-control study in a pastoral community in rural Kenya to identify potential risk factors for brucellosis as a step towards comprehensive understanding of the disease among pastoralists to inform public health interventions.

\section{Main text}

\section{Materials and methods}

\section{Study area and population}

The study was conducted in Arroi, Sultan-Hamud and Mashuru sub-counties in Kajiado East sub-county, Kenya (Fig. 1). The study area is an arid rangeland inhabited primarily by the Maasai nomadic pastoralist community $[23,28]$. The site was selected because a previous study had reported high brucellosis prevalence and because it represent an ecosystem with high frequency of humanlivestock-wildlife interaction $[23,29,30]$.

\section{Study design}

We conducted a hospital based unmatched case-control study in three health facilities that historically had the highest patient load in the year preceding the study. Participants were recruited from 80 randomly selected households in the study area that were part of an ongoing longitudinal brucellosis study in humans and livestock (population $=4792$ people). To enhance case finding at health facilities, recruited household members were sensitized on brucellosis using a community level case definition adapted from the World Health Organisation, and provided with free treatment at the participating health facility [2]. The community case definition for brucellosis used was fever of undetermined origin with at least one of the following symptoms; chills, lethargy, joint pains, body ache, abdominal pain and headaches.

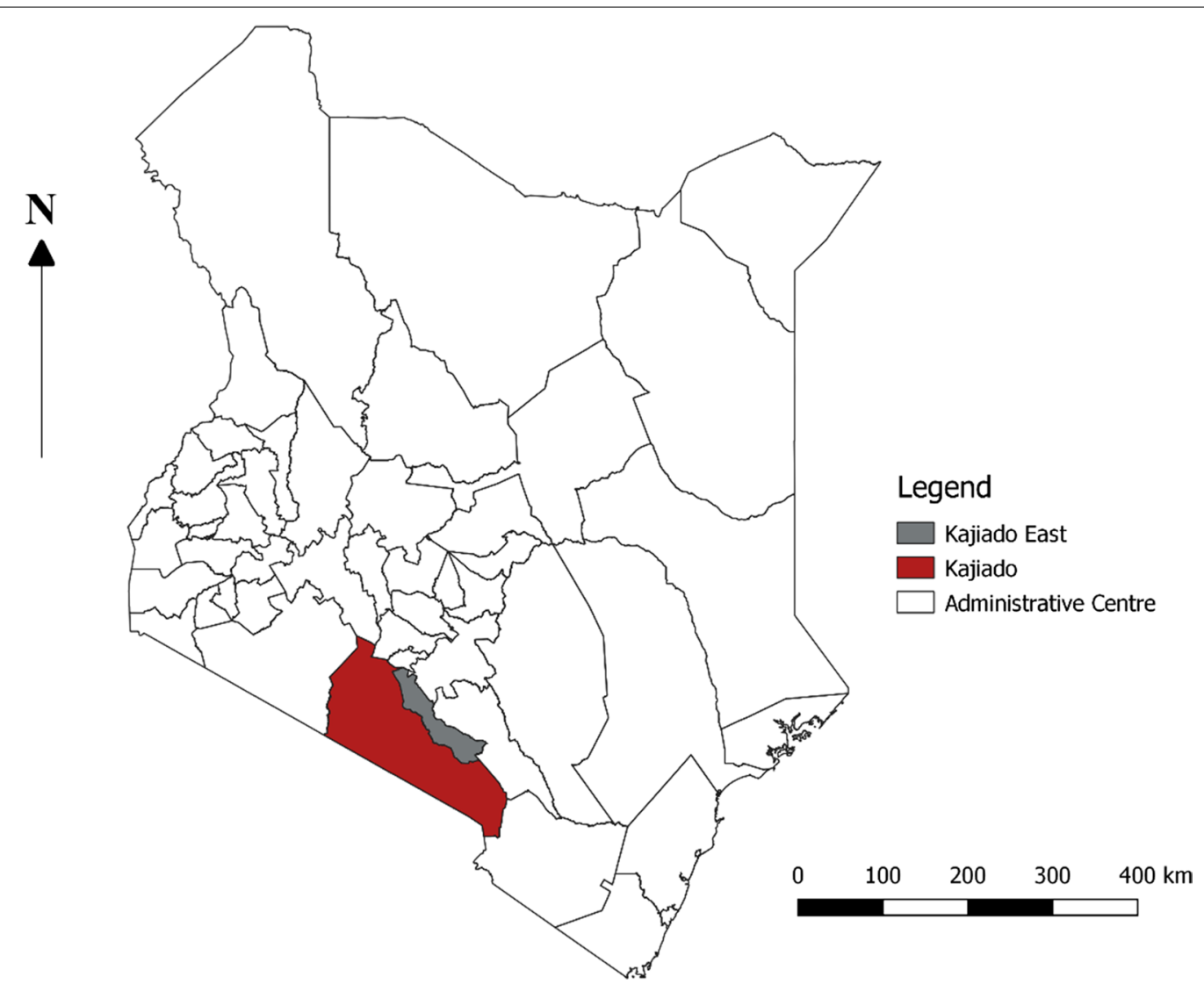

Fig. 1 Map of Kenya showing Kajiado County in red and the study site in grey 


\section{Sample size calculation}

Sample size was calculated using the Kelsey Kelsey formula for unmatched case control studies using an openEpi version 2 open source online calculator (http://www. openepi.com) [31]. The appropriate sample size was determined using a power of 0.8 and significance level of 0.05 to detect an odds ratio greater than 3 for exposure factors present in $20 \%$ of controls as estimated in other similar studies [3, 32]. A control to case ratio of 2:1 was used to improve study power. This yielded a sample size of 43 cases and 86 controls.

\section{Selection of cases and controls}

A case was defined as any person from the study population presenting to any of the three health facilities with fever or history of fever $\left(>37.5{ }^{\circ} \mathrm{C}\right)$ and at-least two of the following signs; joint pains, joint swelling, headache, backache and was negative for malaria and salmonellosis on rapid diagnostic tests and with a positive c-ELISA Immunoglobulin M (IgM) or Immunoglobulin G (IgG) result. A control was defined as a person from the same study population presenting to the study facilities with history of fever within the same study period and was negative for brucellosis by c-ELISA IgM and IgG. Cases were tested for malaria and Salmonellosis because the diseases are common aetiologies of similar clinical disease.

\section{Laboratory testing}

Laboratory testing was carried out at the Kenya Medical Research Institute using IgM and IgG ELISA kit sourced from Immuno-Biological Laboratories, America (Minneapolis, Minnesota). All assays were conducted as per manufacturer's instructions. Briefly, human sera were diluted at 1:10 with sample diluent, added to microtitre plates pre-coated with Brucella antigen (Brucella abortus, strain W99; lysate of a $\mathrm{NaCl}$ extract) and incubated at room temperature for $1 \mathrm{~h}$. Conjugate was added and incubated for $30 \mathrm{~min}$ before adding substrate. The conjugate-substrate reaction was terminated after $20 \mathrm{~min}$ by adding a stop solution. Sample optical densities (ODs) were read at $450 \mathrm{~nm}$. Equivocal samples were not included in analysis.

\section{Questionnaire and interviewing}

A study nurse was stationed in each of the three facilities. Once a patient was identified as a member of the study population during triage (coming from a study household), they were directed to the study nurse who examined them and administered a standard questionnaire pre-loaded on a personal data assistant. The questionnaire collected information on patients' demographic, risk factors, history of illness and point of care test results. Informed consent was obtained from all study participants.

\section{Data analysis}

A number of risk factors were investigated including consumption of goats, sheep, or cow milk, drinking fresh livestock blood, livestock ownership, herding and slaughtering animals, handling skins and hides, and helping in animal delivery. Bivariate analysis was performed using the Chi squared test. Variables with a p-value $\leq 0.10$ in the bivariate analysis were included in a multivariate logistic regression model. Adjusted odds ratios and the corresponding 95\% confidence intervals along with the p-values were reported with significance level being set at $5 \%$. Multivariate logistic regression was used to identify risk factors associated with brucellosis and to estimate the magnitude of the adjusted odds ratios (aORs) for each factor while controlling for other confounding factors. Only the significant variables were included in the model to control for confounding and get a final logistic regression model. Only those variables that had a $p$-value $<0.05$ in the final model were considered statistically significant. Data were analyzed using Statistical Analysis Software (SAS) version 9.2.

\section{Results}

\section{Patient socio-demographic characteristics}

Of the 236 participants from the study population who met the inclusion criteria, majority, $64 \%$ were majority female. Participants had a mean age of 40 years (standard deviation $=16.9$, range $7-75)$ and 129 (54.6\%) of them were enrolled in the case control study, including 43 cases and 86 controls. The mean age for the cases was 48.7 (standard deviation $=20$, range $=10-85$ ) years while that of the controls was 37.6 (standard deviation $=18.8$, range $=8-72)$. Among cases, $70 \%(n=30)$ were between 20 and 59 years. The dominant gender for both cases (62.7\%) and controls (58.1\%) was female. Majority of both cases and controls were non-skilled laborers and there was no significant difference in socio-demographic characteristics (sex, religion, occupation, marital status and education) between cases and controls besides age.

\section{Clinical information}

Sixty percent of the cases presented at-least 7 days after the onset of the first symptom while 37\% presented between 11 and 60 days after onset of symptoms. The mean number of days between onset of symptoms and visit to hospital was 12 days (standard deviation $=13.3$ ). The most commonly reported symptoms by both cases were headache $(83.7 \%)$ back pains $(62.8 \%)$ and joint pains (60.6\%). This was similar to the symptoms reported by 
the controls; headache (82.6\%), back pains (47.7\%) and joint pains $(69.8 \%)$.

\section{Bivariate analysis}

On bivariate analysis, consuming un-boiled cow milk, drinking fresh blood, slaughtering animals (cattle, wild animals), assisting goats in giving birth, handling animal hides were associated with increased risk of brucellosis $(p$-value $\leq 0.1)$. Of these factors, handling skins and hides, assisting goats with delivery, and consuming unboiled goat milk were significantly associated with disease $(p$-value $\leq 0.05)$. Having cattle in the household was found to be protective as shown in the Table 1 .

\section{Multivariable analysis results}

On multivariate logistic regression analysis consuming un-boiled cow milk (OR 7.7, 95\% CI 1.5-40.1) and assisting animals in delivery (OR 3.7, 95\% CI 1.1-13.5) remained significantly associated with brucellosis as shown in Table 2.

\section{Discussion}

Our case-control study identified consumption of raw cow milk, assisting livestock in delivery, and handling animal hides as risk factors on bivariate analysis. However, only assisting livestock in delivery and drinking un-boiled cow milk remained significant risk facts after multivariate analysis. The association between assisting animals with delivery and increased risk of infection has been reported in other studies carried out in similar settings in East Africa [23, 33] Chad [34], the Middle East [35] and in Turkey [36, 37]. Given that Brucella spp. are known to have a predilection for reproductive organs particularly placenta and aborted fetuses, it is logical that assisting animals in delivery increases risk of infection [23]. The risk of brucellosis associated with consumption of un-boiled milk has been well documented [22, 23, 38]. Interestingly, even though most of the pastoralists around the world know about this risk, majority of them still consume raw milk as a tradition and for cultural reasons [39]. Although opinion differs between authors on whether direct contact with livestock (assisting in delivery, milking and feeding) or indirect contact with livestock (consumption of animal products) is a stronger risk factor, we found greater association with disease from consuming animal products than direct contact with animal. This finding is in agreement with other studies carried out within the East Africa region [23, 40, 41]. Studies have shown that consumption of unpasteurized milk is a common practise in Kenya, including communities in urban areas such as where $77 \%$ of households reported the risky practice [42]. Some studies show education and occupation are significant risk factors contrary to our
Table 1 Bivariate analysis of risk factors for human brucellosis

\begin{tabular}{|c|c|c|c|c|}
\hline \multirow[t]{2}{*}{ Variable } & \multirow{2}{*}{$\begin{array}{l}\text { Controls } \\
(n=86) \\
\text { Yes }\end{array}$} & \multirow{2}{*}{$\begin{array}{l}\text { Cases } \\
(n=43) \\
\text { Yes }\end{array}$} & \multirow[t]{2}{*}{$\begin{array}{l}\text { Crude } \\
\text { OR }(95 \% \mathrm{Cl})\end{array}$} & \multirow[t]{2}{*}{$p$-value } \\
\hline & & & & \\
\hline \multicolumn{5}{|l|}{ Consume fresh goat milk } \\
\hline $\begin{array}{l}\text { More than } 3 \text { times a } \\
\text { week }\end{array}$ & 14 & 14 & $2.4(1.0-6.0)$ & \multirow[t]{3}{*}{0.114} \\
\hline $\begin{array}{l}\text { Less than } 3 \text { times a } \\
\text { week }\end{array}$ & 21 & 8 & $0.9(0.4-2.4)$ & \\
\hline No & 51 & 21 & 1.0 & \\
\hline \multicolumn{5}{|l|}{ Consume cow milk } \\
\hline Boiled & 82 & 32 & $7.7(1.5-40.1)$ & \multirow[t]{2}{*}{0.016} \\
\hline Unboiled & 2 & 6 & & \\
\hline \multicolumn{5}{|c|}{ Consume fresh sheep milk } \\
\hline $\begin{array}{l}\text { More than } 3 \text { times a } \\
\text { week }\end{array}$ & 1 & 1 & $2.1(0.1-34.1)$ & \multirow[t]{3}{*}{0.756} \\
\hline $\begin{array}{l}\text { Less than } 3 \text { times a } \\
\text { week }\end{array}$ & 4 & 3 & $1.6(0.3-7.3)$ & \\
\hline No & 81 & 39 & 1.0 & \\
\hline \multicolumn{5}{|l|}{ Drink fresh blood } \\
\hline Yes & 6 & 7 & $2.6(0.8-8.3)$ & \multirow[t]{2}{*}{0.098} \\
\hline No & 80 & 36 & & \\
\hline \multicolumn{5}{|c|}{ Had cattle in the household } \\
\hline Yes & 55 & 26 & $0.1(0.0-0.9)$ & \multirow[t]{2}{*}{0.035} \\
\hline No & 31 & 17 & & \\
\hline \multicolumn{5}{|l|}{ Slaughter cattle at home } \\
\hline Occasionally & 54 & 32 & $2.3(0.8-6.2)$ & \multirow[t]{2}{*}{0.102} \\
\hline Never & 23 & 6 & & \\
\hline \multicolumn{5}{|l|}{ Herding sheep } \\
\hline Several times a week & 16 & 14 & $2.0(0.5-7.8)$ & \multirow[t]{3}{*}{0.196} \\
\hline Occasionally & 49 & 19 & $0.9(0.2-3.2)$ & \\
\hline Never & 9 & 4 & 1.0 & \\
\hline \multicolumn{5}{|c|}{ Assisting sheep in delivery } \\
\hline Several times a week & 1 & 1 & $4.0(0.2-72.2)$ & \multirow[t]{3}{*}{0.116} \\
\hline Occasionally & 45 & 30 & $2.7(1.0-6.9)$ & \\
\hline Never & 28 & 7 & 1.0 & \\
\hline \multicolumn{5}{|c|}{ Slaughtering goats at home } \\
\hline Several times a week & 1 & 1 & $4.8(0.3-90.3)$ & \multirow[t]{3}{*}{0.115} \\
\hline Occasionally & 53 & 33 & $3.0(1.0-8.6)$ & \\
\hline Never & 24 & 5 & 1.0 & \\
\hline \multicolumn{5}{|c|}{ Assisting goats in delivery } \\
\hline Occasionally & 48 & 31 & $3.7(1.3-10.7)$ & 0.043 \\
\hline Never & 29 & 5 & 1.0 & \\
\hline Slaughtering wild anim & & & & \\
\hline Yes & 1 & 3 & & 0.073 \\
\hline No & 82 & 40 & $6.4(0.6-63.2)$ & \\
\hline Cleaning animal barns & & & & \\
\hline Several times a week & 57 & 5 & $0.4(0.1-1.3)$ & 0.132 \\
\hline Occasionally & 19 & 14 & & \\
\hline Handle animal hides & & & & \\
\hline Yes & 30 & 23 & $2.1(1.2-4.5)$ & 0.043 \\
\hline No & 56 & 20 & & \\
\hline
\end{tabular}




$\begin{aligned} & \text { Table } 2 \text { Multivariate } \\
& \text { associated with brucellosis }\end{aligned}$
\begin{tabular}{lll} 
Variable & Adjusted OR (95\% Cl) & p-value \\
\hline Slaughter animals & $6.2(1.1-34.7)$ & 0.350 \\
Handling animal hides & $1.3(0.5-3.6)$ & 0.563 \\
Own cattle & $0.6(0.2-1.6)$ & 0.327 \\
Drinks fresh blood & $3.1(0.8-11.2)$ & 0.088 \\
Assisting livestock in delivery & $3.7(1.1-13.5)$ & 0.050 \\
Drinking un-boiled cow milk & $7.7(1.5-40.1)$ & 0.036 \\
\hline
\end{tabular}

data that shows there was no significant difference on the two variables between cases and controls. A possible explanation is the study area is a rural, predominantly Maasai agro-pastoral community where most households practise a traditional livestock rearing lifestyle. This means that cases and controls have similar occupation and education levels.

\section{Conclusion and recommendations}

The findings of this study show a significant association between infection and consumption of unpasteurized milk and assisting animals with delivery. This findings show that animal handlers; primarily farmers and animal health workers and people who consume unpasteurized milk; a common practise in Kenya, are at the greatest risk. We recommend Public health education on brucellosis transmission and prevention, specifically use of protective personal equipment when assisting animals in delivery and boiling of milk should be offered to farmers and the general public, respectively.

\section{Limitations}

There were some limitations to the study. Case-control studies are prone to selection bias but we took measures to minimise the same; we recruited cases and controls from households participating in an ongoing cohort study of brucellosis in livestock. This meant cases and controls were recruited from households with similar characteristics, which in turn minimises selection bias. Another significant limitation is the limited sample size. The study only recruited cases and controls from an ongoing study that had recruited 810 households with 4792 people; this limited the number of study participants who could be included in our analysis.

\footnotetext{
Abbreviations

AOR: adjusted odds ratio; C-ELISA: competitive enzyme-linked immunosorbent assay; $\mathrm{Cl}$ : confidence interval; IgM: immunoglobulin M; IgG: immunoglobulin G; OD: optical density; OR: odds ration.
}

Authors' contributions

MM was part of the team that designed the study, conducted the field work, data analyses, and did the first draft of the manuscript. AB, AM, EO, DM, ZG, PN ZN, SM, KN supervised the field work and contributed to the study design and manuscript. KN supervised all the work, analyses, and manuscript writing; and designed the study. All authors read and approved the final manuscript.

\section{Author details \\ ${ }^{1}$ Kenya Zoonotic Disease Unit-Ministry of Agriculture, Livestock and Fish- eries and Ministry of Health, P.O. Box 20811-00202, Nairobi, Kenya. ${ }^{2}$ Food and Agriculture Organization of the United Nations, Nairobi, Kenya. ${ }^{3}$ Paul G. Allen School for Global Animal Health, Washington State University, Pullman, WA, USA. ${ }^{4}$ Kenya Medical Research Institute, Nairobi, Kenya. ${ }^{5}$ Kenya Field Epidemiology and Laboratory Training Program, Nairobi, Kenya. ${ }^{6}$ County Gov- ernment of Kajiado, Kajiado, Kenya. ${ }^{7}$ Jomo Kenyatta University of Agriculture and Technology, Nairobi, Kenya.}

\section{Acknowledgements}

We thank the Kenya Directorate of Veterinary Services, Kenya Ministry of Health, County Governments of Kajiado, United States'Centers for Disease Control and Prevention - Kenya Dr. Peninah Munyua (US CDC) for her mentorship and advice during the study and Kenya Field Epidemiology and Laboratory Training Program for their participation in the study.

\section{Competing interests}

The authors declare that they have no competing interests.

\section{Availability of data and materials}

The dataset used and/or analysed during this study is available from the corresponding author on reasonable request.

\section{Consent for publication}

Not applicable.

\section{Disclaimer}

The findings and conclusions in this report are those of the authors and do not necessarily represent the official position of the United States' Defence Threat Reduction Agency or US Centers for Disease Control and Prevention or the Government of Kenya.

\section{Ethics approval and consent to participate}

This study was reviewed and approved by the Kenyatta National Hospital Ethical Review committee. Cases and controls were enrolled after verbal and written consent and no personal identifiers were recorded on the questionnaire. After questioning, participants were provided free medical treatment.

\section{Funding}

Financial support was provided by the United States'Defence Threat Reduction Agency, Kenya Ministry of Agriculture, Livestock and Fisheries, Kenya Ministry of Health and the United States' Centers for Disease Control and Prevention.

\section{Publisher's Note}

Springer Nature remains neutral with regard to jurisdictional claims in published maps and institutional affiliations.

Received: 29 August 2018 Accepted: 29 November 2018

Published online: 05 December 2018

\section{References}

1. Pappas G, Papadimitriou P, Akritidis N, Christou L, Tsianos EV. The new global map of human brucellosis. Lancet Infect Dis. 2006;6(2):91-9.

2. WHO. Brucellosis in humans and and animals (World Health Organization). Geneva: World Health Organization; 2006.

3. Havas KA, Ramishvili M, Navdarashvili A, Hill AE, Tsanava S, Imnadze P, et al. Risk factors associated with human brucellosis in the country of Georgia: a case-control study. Epidemiol Infect. 2013;141(1):45-53. 
4. Young EJ. An overview of human brucellosis. Clin Infect Dis. 1995;21(2):283-9.

5. de Figueiredo P, Ficht TA, Rice-Ficht A, Rossetti CA, Adams LG. Pathogenesis and immunobiology of brucellosis: review of Brucella-Host Interactions. Am J Pathol. 2015;185(6):1505-17.

6. Corbel MJ. Brucellosis: an overview. Emerg Infect Dis. 1997;3(2):213-21.

7. Godfroid J, Scholz HC, Barbier T, Nicolas C, Wattiau P, Fretin D, et al. Brucellosis at the animal/ecosystem/human interface at the beginning of the 21st century. Prev Vet Med. 2011;102(2):118-31.

8. Assenga JA, Matemba LE, Muller SK, Malakalinga JJ, Kazwala RR. Epidemiology of Brucella infection in the human, livestock and wildlife interface in the Katavi-Rukwa ecosystem, Tanzania. BMC Vet Res. 2015;11:189.

9. Franco MP, Mulder M, Gilman RH, Smits HL. Human brucellosis. Lancet Infect Dis. 2007;7(12):775-86.

10. Corbel MJ. Brucellosis: an overview. Emerg Infect Dis. 1997;3:213.

11. Al-Tawfiq JA, Memish ZA. Antibiotic susceptibility and treatment of brucellosis. Recent Pat Anti Infect Drug Discov. 2013;8(1):51-4.

12. Seleem MN, Boyle SM, Sriranganathan N. Brucellosis: a re-emerging zoonosis. Vet Microbiol. 2010;140(3-4):392-8.

13. Ulu-Kilic A, Metan G, Alp E. Clinical presentations and diagnosis of brucellosis. Recent Pat Anti Infect Drug Discov. 2013;8(1):34-41.

14. Díaz R, Casanova A, Ariza J, Moriyón I. The rose Bengal test in human brucellosis: a neglected test for the diagnosis of a neglected disease. PLoS Negl Trop Dis. 2011;5(4):e950.

15. Baba MM, Sarkindared SE, Brisibe F. Serological evidence of brucellosis among predisposed patients with pyrexia of unknown origin in the north eastern Nigeria. Cent Eur J Public Health. 2001;9(3):158-61.

16. Dean AS, Crump L, Greter H, Schelling E, Zinsstag J. Global burden of human brucellosis: a systematic review of disease frequency. PLoS Negl Trop Dis. 2012;6(10):e1865.

17. Shevtsova E, Shevtsov A, Mukanov K, Filipenko M, Kamalova D, Sytnik I, et al. Epidemiology of brucellosis and genetic diversity of brucella abortus in Kazakhstan. PLoS ONE. 2016;11(12):e0167496.

18. Maurin M. Brucellosis at the dawn of the 21st century. Med et Maladies Infect. 2005;35(1):6-16.

19. McDermott J, Grace D, Zinsstag J. Economics of brucellosis impact and control in low-income countries. Revue Sci et Tech (International Office of Epizootics). 2013;32(1):249-61.

20. Godfroid J. Brucellosis in livestock and wild life: zoonotic diseases without pandemic potential in need of innovative one health approaches. Arch Public Health. 2017;75:34.

21. Munyua P, Bitek A, Osoro E, Pieracci EG, Muema J, Mwatondo A, et al. Prioritization of Zoonotic Diseases in Kenya, 2015. PLoS ONE. 2016;11(8):e0161576.

22. Njeru J, Wareth G, Melzer F, Henning K, Pletz MW, Heller R, et al. Systematic review of brucellosis in Kenya: disease frequency in humans and animals and risk factors for human infection. BMC Public Health. 2016;16(1):853.

23. Osoro EM, Munyua P, Omulo S, Ogola E, Ade F, Mbatha P, et al. Strong association between human and animal brucella seropositivity in a linked Study in Kenya, 2012-2013. Am J Trop Med Hyg. 2015;93(2):224-31.

24. Omballa VO, Musyoka RN, Vittor AY, Wamburu KB, Wachira CM, Waiboci LW, et al. Serologic evidence of the geographic distribution of bacterial zoonotic agents in Kenya, 2007. Am J Trop Med Hyg. 2016;94(1):43-51.

25. Maichomo MW, McDermott JJ, Arimi SM, Gathura PB, Mugambi TJ, Muriuki SM. Study of brucellosis in pastoral community and the evaluation of the usefulness of clinical signs and symptoms in differentiating it from other flu-like diseases. Afr J Health Sci. 2000;7:114-9.

26. McDermott JJ, Arimi SM. Brucellosis in sub-Saharan Africa: epidemiology, control and impact. Vet Microbiol. 2002;90:111-34.

27. Ari MD, Guracha A, Fadeel MA, Njuguna C, Njenga MK, Kalani R, et al. Challenges of establishing the correct diagnosis of outbreaks of acute febrile illnesses in Africa: the case of a likely Brucella outbreak among nomadic pastoralists, northeast Kenya, March-July 2005. Am J Trop Med Hyg. 2011;85(5):909-12.

28. Galvin KA, Beeton TA, Boone RB, BurnSilver SB. Nutritional status of Maasai pastoralists under change. Hum Ecol. 2015;43(3):411-24.

29. O'Brien MP, Beja-Pereira A, Anderson N, Ceballos RM, Edwards WH, Harris $B$, et al. Brucellosis transmission between wildlife and livestock in the greater yellowstone ecosystem: inferences from DNA genotyping. J Wildl Dis. 2017;53(2):339-43.

30. Tanner M, Inlameia O, Michel A, Maxlhuza G, Pondja A, Fafetine J, et al. Bovine tuberculosis and brucellosis in cattle and African buffalo in the Limpopo National Park, Mozambique. Transbound Emerg Dis. 2015;62(6):632-8

31. Dean AG SK, Soe MM. Open Source Epidemiologic Statistics for Public Health. 2016.

32. Abo-Shehada MN, Abu-Halaweh M. Risk factors for human brucellosis in northern Jordan. East Mediterr Health J. 2013;19(2):135-40.

33. John K, Fitzpatrick J, French N, Kazwala R, Kambarage D. Quantifying risk factors for human brucellosis in rural northern Tanzania. PloS ONE. 2010;5:e9968

34. Schelling E, Diguimbaye C, Daoud S, Nicolet J, Boerlin P, Tanner M, et al. Brucellosis and Q-fever seroprevalences of nomadic pastoralists and their livestock in Chad. Prev Vet Med. 2003;61(4):279-93.

35. Cooper CW. Risk factors in transmission of brucellosis from animals to humans in Saudi Arabia. Trans R Soc Trop Med Hyg. 1992;86(2):206-9.

36. Kutlu M, Ergonul O, Sayin-Kutlu S, Guven T, Ustun C, Alp-Cavus S, et al. Risk factors for occupational brucellosis among veterinary personnel in Turkey. Prev Vet Med. 2014;117(1):52-8.

37. Deniz S, Baykam N, Celikbas A, Yilmaz SM, Guzel TC, Dokuzoguz B, et al. Screening household members of acute brucellosis cases in endemic areas and risk factors for brucellosis. Vector Borne Zoonotic Dis. 2015;15(8):468-72.

38. Arimi SM, Koroti E, Kang'ethe EK, Omore AO, McDermott JJ. Risk of infection with Brucella abortus and Escherichia coli 0157:H7 associated with marketing of unpasteurized milk in Kenya. Acta Trop. 2005;96(1):1-8.

39. Kansiime C, Mugisha A, Makumbi F, Mugisha S, Rwego IB, Sempa J, et al. Knowledge and perceptions of brucellosis in the pastoral communities adjacent to Lake Mburo National Park, Uganda. BMC Public Health. 2014;14:242.

40. Asiimwe BB, Kansiime C, Rwego IB. Risk factors for human brucellosis in agro-pastoralist communities of south western Uganda: a case-control study. BMC Res Notes. 2015;8(1):405.

41. Tumwine G, Matovu E, Kabasa JD, Owiny DO, Majalija S. Human brucellosis: sero-prevalence and associated risk factors in agro-pastoral communities of Kiboga District, Central Uganda. BMC Public Health. 2015;15:900.

42. Namanda AT, Kakai R, Otsyula M. The role of unpasteurized "hawked" milk in the transmission of brucellosis in Eldoret municipality, Kenya. J Infect Dev Ctries. 2009;3(4):260-6.

Ready to submit your research? Choose BMC and benefit from:

- fast, convenient online submission

- thorough peer review by experienced researchers in your field

- rapid publication on acceptance

- support for research data, including large and complex data types

- gold Open Access which fosters wider collaboration and increased citations

- maximum visibility for your research: over 100M website views per year

At BMC, research is always in progress.

Learn more biomedcentral.com/submissions 